\title{
Tradition and Originality in Raphael: The Stanza della Segnatura, the Middle Ages and Local Traditions
}

\author{
David Rijser
}

However much has changed in Renaissance studies, the iconicity of Raphael's School of Athens in the Vatican Stanze tenaciously continues to hold sway, even when scholars seemingly undermine it by innovative research. Thus a recent attempt to explore undeniably new ways of looking at functions and versions of the past in Renaissance culture eventually cedes to 'the compulsion to end the account with Raphael'. ${ }^{1}$ Concluding their study of the interaction between the "substitutional" (that is, art independent of time, author and style but as an instance in a chain of replicas) and the "performative" (art as authorial enunciation) in Quattrocento artistic production, Nagel and Wood in Anachronic Renaissance present a Raphael rightly seen à cheval. Stunningly innovative and stylistically individualized as Raphael's frescoes were, they were in fact positioned within a traditional context of a (pseudo-) mosaic ceiling and a (neo-) cosmatesque pavement, a defining frame the modern viewer all too easily blocks out of view, concentrating instead on the frescoes as easelpieces. ${ }^{2}$ Yet if Raphael's art indeed advanced a highly individual artistic claim for excellence, it did so quite consciously within a monumental context that played the old game of reproducing form including its "atmosphere" that was as highly traditional [Fig. 4.1].

The authenticating function of "substitution" as construed by recent scholarship is surely relevant for the search for an appropriate past studied in this volume. ${ }^{3}$ The recreation of ambience and concomitant content was the essential tool with which to manipulate visitors and viewers of representative space

1 Nagel A. - Wood C.S., Anachronic Renaissance (New York: 2010) 358. See also (independently) Rijser D., Raphael's Poetics. Art and Poetry in High Renaissance Rome (Amsterdam: 2012) 246-247.

2 Although Nagel \& Wood also acknowledge 'traditional' motifs in the content of Raphael's frescoes, including the apse-iconography in the Disputa, they do not pursue the possibilities offered here.

3 Apart from Anachronic Renaissance, see e.g. Belting H., "In Search of Christ's Body: Image or Imprint?", in Kessler H.L. - Wolf G. (eds.), The Holy Face and the Paradox of Representation

(C) DAVID RIJSER, 2019 | DOI:10.1163/9789004378216_006

This is an open access chapter distributed under the terms of the prevailing CC-BY-NC-ND License at the time of publication. 


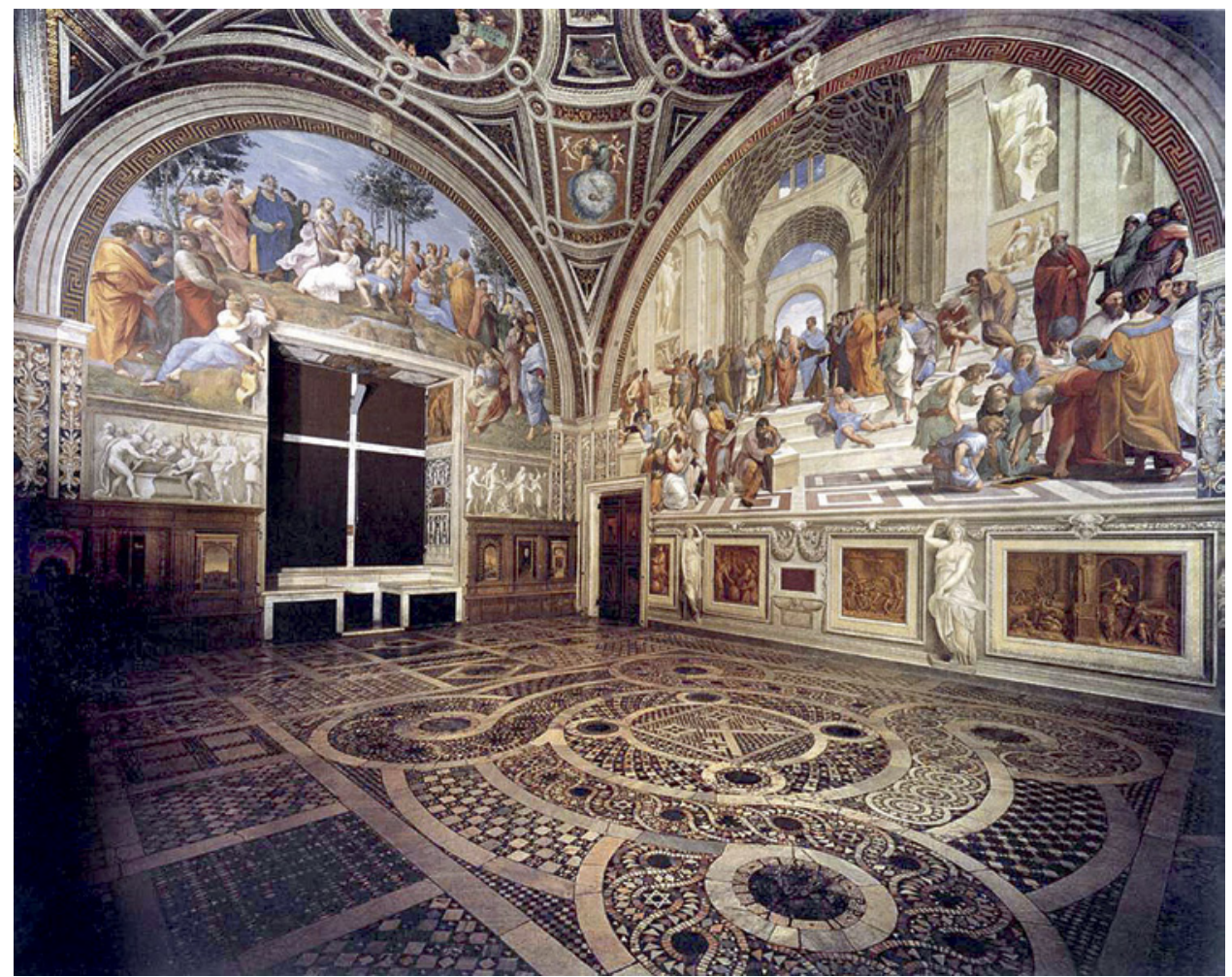

FIG URE 4.1 Raphael, School of Athens and Parnassus framed by pavement and ceiling. Stanza della Segnatura, Vatican City, Rome IMAGE (C) PUBLIC DOMAIN

into accepting as natural the traditions their patrons wanted to appropriate or associate themselves with. There is no doubt that Julius II as patron of the Stanza della Segnatura wanted to do just that. Yet the observation of Nagel and Wood that, apart from the classical past, medieval traditions played a significant role in the Stanza as well can be taken further. In fact, a more radical application of the concept of substitution than that performed by the closing chapter of Anachronic Renaissance may suggest in what way and for what purpose Julius II connected to tradition in the Stanza. This argument entails a demonstration of Raphael's embeddedness in "medieval" iconography in a

(Bologna: 1998) 1-11 and now Thunø E., The Apse Mosaic in Early Medieval Rome. Time, Network and Repetition (Cambridge: 2015). 
much more profound sense than has been usual for quite some time. ${ }^{4}$ As a consequence, the inveterate tendency of critics to be drawn to the School of Athens as moths to a flame appears in a different light, and our attention is allowed to move to the proper focal point, the Disputa, at least from the perspective of a reading of the ensemble consistent with local tradition. ${ }^{5}$ When the argument of the papers in this volume is taken at all seriously, we should a priori try and interpret the Stanza in connection with its past rather than, as has been done too often, its future as the cradle of Classicism. The fascinating thing is that this issue, in this case as well, is the recent medieval past as much as the more distant classical past.

But we need to begin with the classical tradition Raphael has long been seen to epitomize. As the reader of the present collection will notice time and again, the traditional focus on classical antiquity in Renaissance studies seriously distorts the actual diversity of early modern attitudes towards the past. When broadening the scope of research as attempted here, both periodization of what was considered classical, and the topographical and cultural unity of the classical tradition seem to become fluid. This allows us at least three important perspectives: to view local traditions as bearers of historical and cultural authorisation and legitimation on a par with the classical pasts of Greece and Rome; second, to mistrust the topical Renaissance affirmation of historical otherness, the alleged discontinuity with the recent past that is so central to the agenda of humanists like Petrarch or Valla, and finally, by contrast, become even more aware than previously of striking continuities with what we now call medieval traditions at the very same time. ${ }^{6}$

Such a view of Renaissance culture, however, poses a problem. For the classical "otherness" we had for so long been accustomed to call "Renaissance", is prominently present in Raphael's frescoes. It would be as counterintuitive to deny the relevance of the art and culture of classical antiquity for the decoration of the Stanza, as it would be to do so for the Latin of Petrarch and

4 Notable exceptions being two articles by Arnold Nesselrath, "Raphael and Pope Julius II", in Chapman H. - Henry T. - Plazotta C. (eds.), Raphael, from Urbino to Rome, exh. cat., The National Gallery London (London: 2004) 280-293 and "Raffaels Madonna von Foligno", in Henning A. - Nesselrath A. (eds.), Himmlischer Glanz. Raffael, Dürer und Grünewald malen die Madonna, exh. cat., Old Masters Gallery Dresden (Munich: 2012) 40-51, from which I take my cue, gratefully acknowledging also personal communication of the author that proved essential for the present article.

5 A failure to grasp the directional dynamics of the room is the main deficiency of Nagel and Wood's interpretation.

6 This has been an on-going project in scholarship from the mid-2oth century. For local traditions, different periodisations and continuities with the Middle Ages, see the introduction to this volume. 


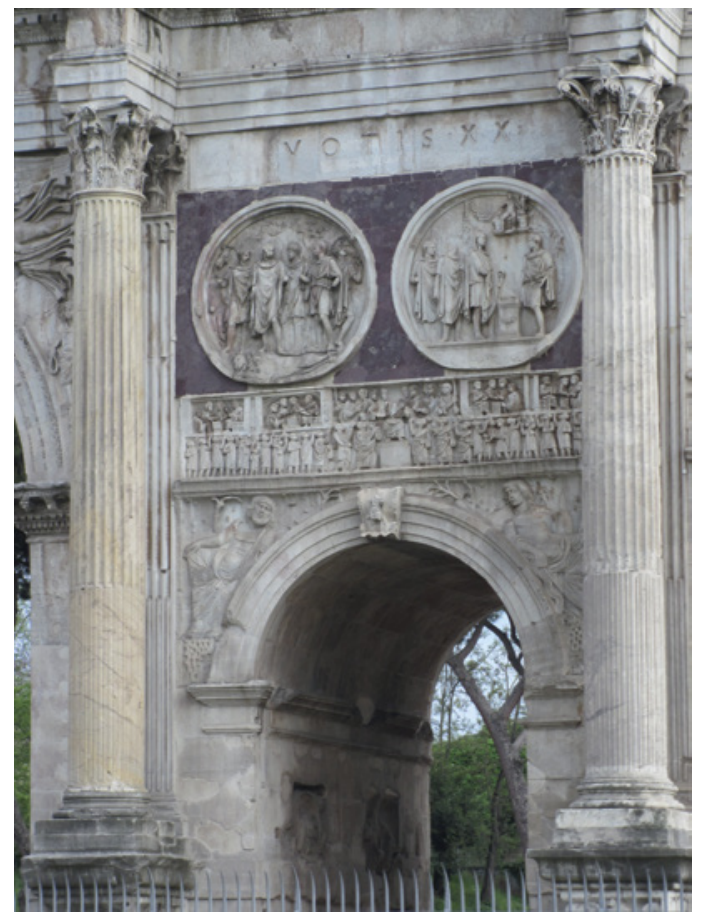

FIGURE 4.2

Arch of Constantine, Rome. Detail from the northern façade with the Hadrianic tondi IMAGE C KONRAD OTTENHEYM

Valla. This goes for both content and style. Once more making an example of the School of Athens: it contains identifiable portraits of Socrates, Plato and Aristotle, and inscriptions of two important works of the latter two; a location moreover evidently evoking antique monumental architecture and sculptural decoration; its narrative (if narrative it is) unfolds under the aegis of Apollo and Minerva; ${ }^{7}$ on top of it all, in the vault, a presiding personification inscribed with the Latin tag cognitio causarum and seated on a throne supported by the very classical Ephesian Artemis. Lastly, and historically at least as importantly, style: Raphael's representation of figures in space and the ordering of space itself, has since Vasari been seen as his greatest triumph. That triumph arguably owes much to the painter's close inspection of the Hadrianic tondi of the Arch of Constantine - as is evinced by the evaluation of this Arch in Raphael's letter to Leo $\mathrm{x}$ [Fig. 4.2]. ${ }^{8}$

7 Narrativity in the Stanza would be rewarding to analyse systematically: on the face of it, it is restricted to liminal areas (e.g., on the School of Athens again, the warding off of the messenger on the upper left-side, the spiegazione of 'Bramante' on the lower right and the scene of composition with 'Inghirami' on the lower left).

8 Although at the time attributed to the time of Antoninus Pius, see Shearman J., Raphael in Early Modern Sources (New Haven: 2003), vol. I, 504, 512, 520. 
From that letter it appears that Raphael and his advisers saw a sharp decline of sculptural quality around the third century AD, soon followed by a parallel decline of harmonious architectural form somewhat later, at the time of $i$ Goti e altri barbari, presumably referring to the northern peoples that swept over Italy from the early $5^{\text {th }}$ century onwards. If the phrasing remains vague, the general drift is quite clear: decline set in 'from the time when Rome was despoiled and ruined by the Goths and other barbarians, lasting from that time until the Gothic domination of Rome and for one hundred years afterwards. ${ }^{9}$

Raphael's views on the periodization of classicism are thus attested in authentic pronouncements as co-author (with the help of his humanist friend Castiglione) of an official letter to the Pope, that explicitly stigmatizes 'Gothic' art and architecture as opposed to the classicism of the imperial period that was to be revived by Leo's court. ${ }^{10}$ The letter no doubt contains special pleading: its argument is closely connected with the task the writer is to perform, that is, the production of a reconstruction of the ancient city. Yet this does not detract from the forceful implementation of a chronology following the format of (classical) flowering - (Medieval) decadence - Renaissance.

This picture that emerges from the letter to Leo can be corroborated from other sources. Directly after his untimely death at Good Friday 1520, Raphael was praised in an unusual profusion of literary epigrams, of which the one by Bembo that now graces his sepulchral monument is merely the most famous. Without fail, these epigrams mention this very 'restoration of ancient Rome' as Raphael's main claim to fame. That in itself, in Rome, would not be a revolutionary claim: the continuity of the eternal city could only be, and was indeed realized through the medium of restoration and renovation. The striking novelty was that a restoration of classical Rome was claimed on behalf of Raphael, for Raphael's activities are represented as a pious restitution, restoration and renovation of a cultural zenith in the classical past. Thus, the discourse on Raphael's activities as a restoration of ancient excellence stressed a gap in time

9 'Anzi, dico che con poca fatica far si può, perché tre sorti di edifici in Roma si trovano: l'una delle quali sono tutti gli antichi ed antichissimi, li quali durarono fin al tempo che Roma fu ruinata e guasta da' Gotti e altri barbari; l'altra, tanto che Roma fu dominata da' Gotti, e ancor cento anni dappoi; l'altra, da quello fin alli tempi nostri' (Shearman, Raphael, vol. I, 520; for a bibliography of the letter ibidem 544-545). Gothic domination probably refers to the 'German' Holy Roman Emperors; with the 'addition of a century' the middle period would then extend to the Trecento. One example given of 'bad' architecture, the Torre delle milizie, indeed dates from the 13th century.

10 The relative contribution of the authors of the letter is hotly debated, yet the collaboration and by implication approval of contents of Raphael is beyond controversy. For a convenient overview of opinions see Shearman, Raphael, vol. I, 537-543. 
and, with it, in mentality between the substituting present and the past of which it performs substitutions. ${ }^{11}$

That Renaissance Romans saw especially classical Rome in the late Republic and early Empire as their appropriate past, is as evident as are the reasons for it. Rome had been for a time without unblemished splendour, or so it had been suggested by the envious - indeed it had been tainted and humiliated by the Babylonian Captivity. It thus stood in dire need of exclusive ownership of the greatness others continually tried to wrest from her. Hence curials started looking for things specifically and authentically Roman. This naturally entailed a focus on the point of time that had established Roman power in its definitive form, at the same time formed the highpoint and zenith of Roman culture, point of reference for all time to come, and last but not least coincided happily with the birth of a new culture and truth, in the form of Christ the King. That is why the period around the beginning of Christ's era was so much more exclusively courted, studied and imitated especially in Rome.

Hence also the tendency, explicitly stated in the historical overview in the first book Girolamo Vida of De arte poetica of 1527, to construe literary history as suffering a sharp decline after Cicero and Virgil, only to be revived in the present: this would stress the elective affinity between the receiving culture, the papal court in the Renaissance, and its typological source and counterpart, the establishment of Empire by Augustus and, in tandem, the birth of Christ. ${ }^{12}$

Thus as it were a fifth column of 'historicity' entered the medieval practice of renewal through substitution, that is, the habit of 'replacing' an iconic image or text (differently put: creating a new work in an ancient tradition) was performed with the addition of its projection onto an evaluative time-scale to determine its value; this is exactly what Valla's preface to the Elegantiae, the letter to Leo and Vida's De arte poetica do. The particular desideratum in cultural matters now became the imitation of the best authors and the perfect style from the cultural zenith of Rome rather than the tradition as a whole, or

11 Texts in Shearman, Raphael, vol. I, s.v. 1520-1521. For discussion see Rijser D., "The Funerary Epigrams on the Painter Raphael: message, function and afterlife", in Beer S. de - Enenkel K.A.E. - Rijser D. (eds.), The Early Modern Latin Epigram: Towards a Definition of Genre (Louvain: 2009) 101-131, and Rijser, Raphael's Poetics 29-85.

12 Vida De arte poetica I, 178-195. It is tempting to attribute the chronologically and topographically more purist Classicism of Raphael, Castiglione and Vida to a change of taste and style under the pontificate of Leo, the historical circumstance of which created an increasing awareness of the need for an "archaeological correctness" polemicizing with the Reformation from the "barbarian" North. This may have played a role (as it did in many other cases), but as the prefaces to Valla's Elegantiae attest, in more general terms the discourse was already there. 
in general. To be sure, this would not have been possible without two precedents. In the first place Petrarch, who had been motivated by different reasons, but had nonetheless constructed a classical paradigm that had subsequently been developed in Florentine circles and beyond..$^{13}$ In the second place, this involvement of the historical in the cultural discourse of nascent Classicism was a revival of arguments from Antiquity itself: for both the implementation of an evaluative historical time-scale, and the identification of a Golden Age of culture (for Roman literature the late Republic and early Empire) were part of the discourse of political and cultural history already in Antiquity, as Renaissance observers could read in e.g. Quintilian and Aulus Gellius. ${ }^{14}$ These two precedents, Petrarch's battle-cry for moral regeneration through a confrontation with classical culture in its hey-day, and the discourse of cultural peaks in antiquity itself, could now be harnessed into papal service at the appropriate location, which, of course, could be none other than Rome. The up-shot of all of this is that we are allowed to see more clearly that Classicism, which in the course of its long reign increasingly pretended to encode universal aesthetic (and political) Truths - as indeed universalist tendencies had been clearly present in the venerated examples of Cicero and Virgil - started out on its historical course as a local, Roman tradition.

In an ambience fraught with political and historical claims of superiority as the Stanza della Segnatura, Julius's II oval office, the presence of classical references, both more general and specifically to the foundational period of the Empire, were natural. But then, what about continuities with the Middle Ages? The answer may be found in the very observation prompted above: that the Roman Classicism of the early Cinquecento initially pointed not to a universal, but to a very local tradition. If so, it is likely that traces of local traditions and 'local' history would surface in the form of continuities with medieval traditions, either lurking beneath the surface of the evaluative historicism that we discussed above, or simply there before our noses, unregistered because we used to look in the wrong way.

From this perspective, let us look at the Stanza della Segnatura, the paragon of Classicism, once more. The standard version tacitly assumes that Raphael's classical triumph was won over a recent, medieval past now finally discarded thanks to Raphael's classical style, reborn and reaffirmed in contrast with medieval primitivism. Up till now, this surely is what we expect. Yet if so, the visitor of the Vatican Stanze is in for a number of surprises. For one thing, references to the Middle Ages in the Vatican Stanze are extremely frequent. Not

13 See e.g. Panofsky E., Renaissance and Renaissances (London: 1957) 10-18.

14 Quintilian X, 1-13; Gellius XIX, 8,15. 
even counting what we would call "late-antique" or "early Christian", it is medieval subject-matter that dominates, in the Coronation of Charlemagne of 80o, the Fire in the Borgo of Leo IV making the sign of cross in 847 and the Battle of Ostia of 849. In the Segnatura itself there is the Dedication of the Decretals of 1230 and in the Eliodoro the Miracle at Bolsena, the 1263 incident of blood materializing on the corporal of a doubting priest. In fact, tabulation of subject matter in the Stanze yields the alarming result that there are only two iconographical subjects exclusively and explicitly corresponding with what subsequently would be called classical: the Flaying of Marsyas in the vault of the Segnatura, and the set of grisaille scenes from Roman history in the same vault. The latter by the way are miniature. Apparently, the 'classical' in the Stanza has little to do with periodization.

Indeed in the Stanze, wherever classical personnel is depicted, such as the School of Athens or the Parnassus, it is always in combination with characters from later periods. In the trans-historical scenes that form the bulk of the Segnatura no specific historic occasion is represented, and accordingly a consistent mixture of historical personnel in which the medieval is just as significant as the antique. This very mixture in fact shows that no contrast whatsoever with the Middle Ages in the Stanze was intended: everything in these frescoes is directed towards the themes of transmission, reception and continuity. 15

Protagonists from quite diverse periods and locations converse without effort on the walls of the Segnatura, as was recognized by observers from the outset as a matter of course. It would have been quite unnatural to think otherwise, considering the tradition of uominifamosi that the Stanza refers to and in which exactly the same applies. Thus Zoroaster and Ptolemy mingle with Bramante and Michelangelo, Avicenna with Diogenes. Raphael's addition to that tradition, however, is telling: for he depicts his characters emphatically in the act of sharing knowledge, communicating, copying, explaining. The same goes for the Disputa, with its trans-historical discussion of the miracle of Transsubstantiation, where Church fathers are happily gathered with medieval theologians and Popes, and share views rather than fight out their differences [Fig. 4.3]. If ever there was an image of continuity, this is it.

An aspect of the late antique and medieval scenes illustrates this continuity in yet another way. For by the look of it the most striking aspect of the formal representation of the scenes mentioned above seems to be that the Middle

15 This is in fact a commonplace in criticism, see e.g. Rijser, Raphael's Poetics 11-19 and, with a nice example, Hall M., "Introduction", in Hall M. (ed.), Raphael's School of Athens (Cambridge: 1997) 13 . 


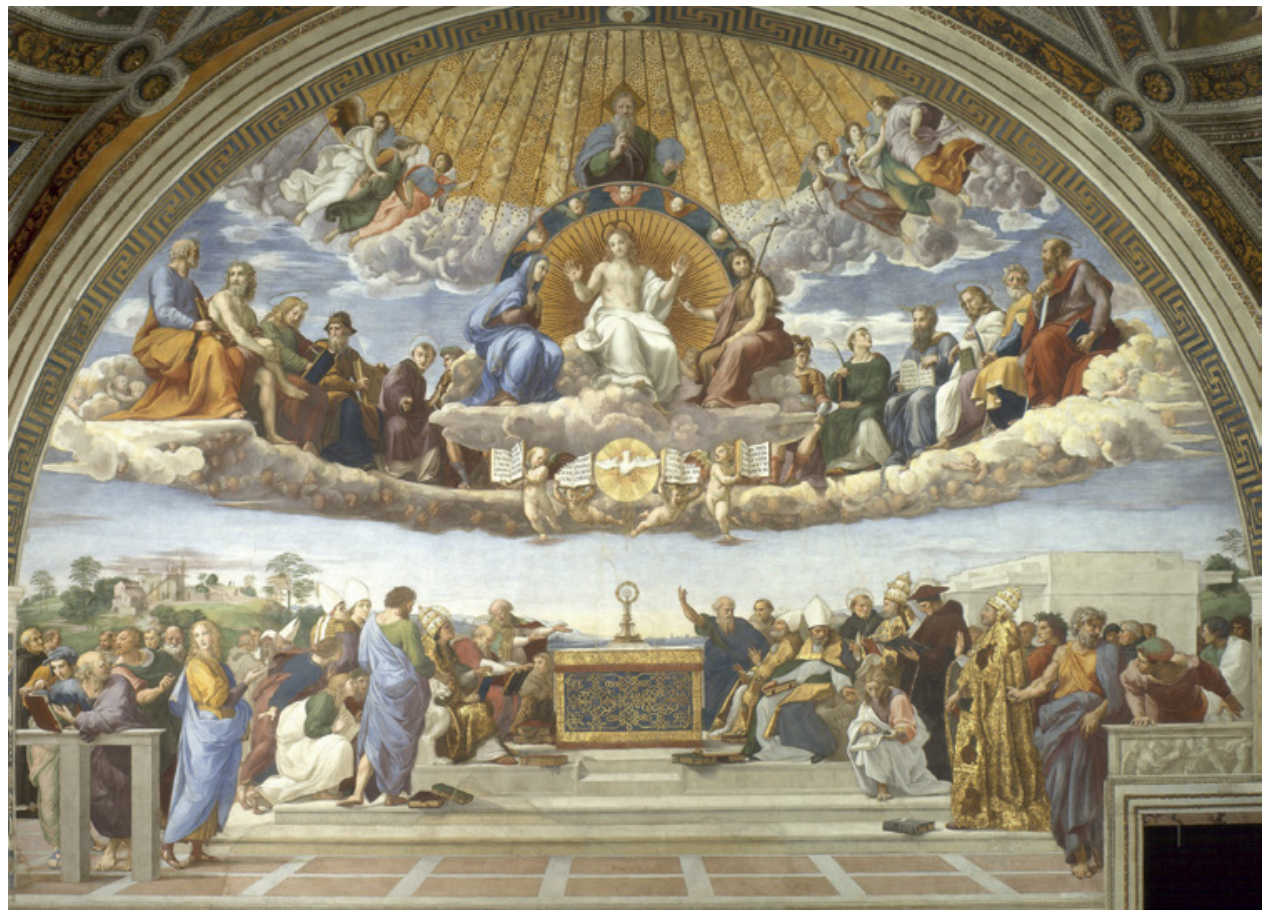

FIGURE 4.3 Raphael, Disputa. Stanza della Segnatura, Vatican City, Rome IMAGE (C) PUBLIC DOMAIN

Ages never happened at all. Hardly any visual differentiation between medieval and other scenes obtains: ${ }^{16}$ people from Rome are dressed as Romans either secular or clerical (and we should remember that clerical dress code is spun off from ancient Roman practice); soldiers wear Roman armour, architecture is Roman [Fig. 4.4]. ${ }^{17}$ This is not merely an example of the tendency studied elsewhere in this volume, namely the extension of 'antiquity' to the very recent past. This evident refusal of Raphael and his workshop to differentiate these medieval scenes historically from classical Antiquity results in the suggestion that the medieval past is seamlessly included in a total concept of Roman-ness, and Roman-ness of course should be dressed properly, in classical garb. Thus here, contrary to the letter to Leo, there is not a trace of historicism: rather, we may be reminded of Valla's triumphant claims for the rule of the

16 A minimum in the Battle of Ostia, with soldiers wearing trousers and what looks like the Quattrocento Castle of Ostia complete with battlements.

17 Architecture: e.g. Decretals, Coronation, Fire in the Borgo; Dress: Fire in the Borgo, Decretals; soldiers: Battle of Ostia. 


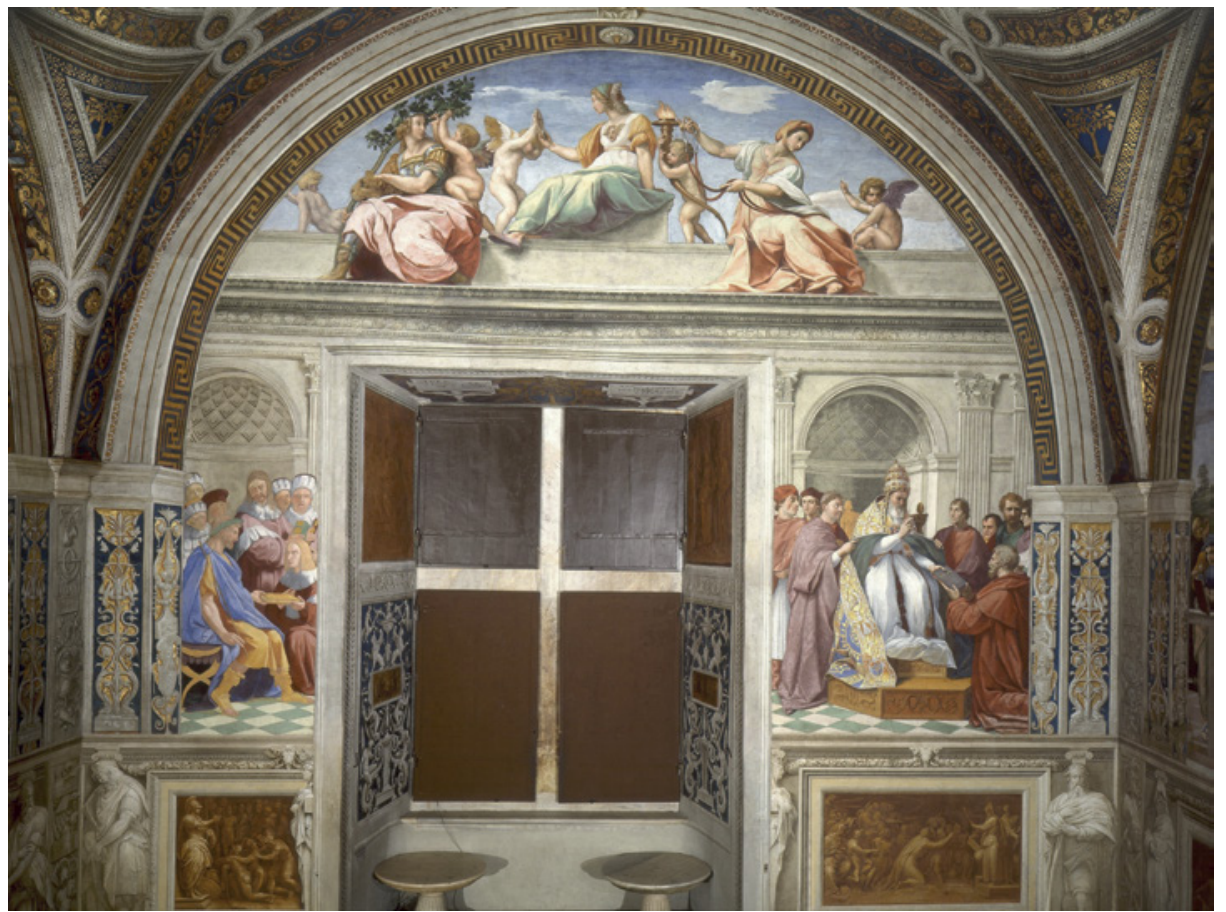

FIGURE 4.4 Raphael (with Lorenzo Lotto), Scenes illustrating Justice. Stanza della Segnatura, Vatican City, Rome

IMAGE (C) PUBLIC DOMAIN

Latin language: 'Ibi namque romanum imperium est, ubicumque romana lingua dominatur' ('wherever the Latin language reigns, there the Roman Empire is'), reconfigured here to the visual statement that wherever the pope is, there is Rome. ${ }^{18}$ Not a trace of contrastive intrusion of medieval elements in an otherwise classicistic formal language is hinted at; yet medieval elements, totally absorbed and thoroughly at home, are very much there. ${ }^{19}$ Used to considering the Stanza the paragon of Classicism, we tend to overlook this.

The inveterate tendency to see classicism as the norm in the Segnatura creeps up in unobtrusive yet decisive ways. One of them is the point of departure of discussion. To start a discussion with the School of Athens, as so

18 Valla Lorenzo, "In sex libros elegantiarum praefatio", in Garin E. (ed.), Prosatori Latini del Quattrocento (Turin: 1977) 596.

19 That the Middle Ages were all over the High Renaissance Vatican, appears also in other fields, of course. See Rowland I.D., "The Intellectual Background", in Hall M. (ed.), Raphael's School of Athens (Cambridge: 1997) 131-170. 
many from Vasari onwards have done, both implies a choice of focus on one single item, and suggests some pride of place for this image in particular. The very application of the title School of Athens already makes the point: for that title suggests both classical content and, being a "school", a normative value of classical culture. ${ }^{20}$ Yet the Segnatura is a square room. It thus contains two principal axes and four iconic images, creating in principle a network of interconnections. If we are to look for priorities, we should follow visual clues. These Raphael has provided by having Plato and Aristotle in the School of Athens walk in a direction, namely of the Disputa on the other side. In other words, the School of Athens does not pose as a central shrine, an altar of some sorts - of Classicism as seems to be the suggestion indeed when it is seen out of context - but as a point of departure, as indeed it was for any visitor, who would enter the room through the very wall from which Plato an Aristotle set out their journey to the altar opposite. ${ }^{21}$

When considering the axis of the room thus created, the visual logic of the space instructs us to grant prevalence to that other side towards which the movement is directed, and we immediately sense the dynamics of the symbolic route through a Church, from atrium to apse. ${ }^{22}$ That this apse in fact has a western rather than proper eastern orientation, may raise an eyebrow. But in fact the majority of early medieval apses in Rome was oriented to the west. ${ }^{23}$ Indeed the Segnatura thus follows the orientation of the Sistine Chapel and Saint Peter's Basilica. The Disputa being conceived of as an apse implies a ritual and iconographical code of orientation towards the light of Christ. This direction of attention moreover evokes the glory of late antique and medieval Rome, her apse decorations from the Santa Pudenziana, via the Carolingian flowering in the 9 th century, to the Indian summer of the $13^{\text {th }}$ century. ${ }^{24}$

20 It is interesting to speculate what those who employ this title mean by 'school': the depiction of processes of education in Athens, or the educational, and moral value of Athenian speculation. The same problem in Thucydides' endlessly quoted phrase paideia Hellados, see Most G., "Athens as the School of Greece", in Porter J.I. (ed.), Classical Pasts (Princeton: 2006) 379-385.

21 Nagel - Wood, Anachronic Renaissance 363 still exemplify the tendency to consider the School of Athens as a central, autonomous image and easel piece, wondering why it has not got an altar. For the importance of the concept of easel-pieces and its history, see Puttfarken T., The Discovery of Pictorial Composition (New Haven: 2000).

22 The other principal directional axis is from 'Justice' to 'Parnassus', see Rijser, Raphael's Poetics ${ }^{155^{-1}}$ 6.

23 Following the original shrine for Saint Peter's grave. See also Thunø, The Apse Mosaic 132.

24 Especially Arnold Nesselrath has pointed out how essential the iconography of the Disputa and its connections to the 'School of Athens' are for a proper understanding of the room (Nesselrath, "Raphael and Pope Julius" 285-288). 
If selecting as our companions Plato and Aristotle we follow in their footsteps and walk from the School of Athens to the altar of the Disputa, we share an itinerary followed by anyone who had visited a Roman church and partook of the ritual since the swaddling clothes of Christianity. This itinerary to the "light" represented by altar and apse was also a way, of course, to Christ and to community with Christ and the Saints. ${ }^{25}$ In apse-scholarship, much is made of the dramatic aspects of this mini-pilgrimage of the worshiper to the altar and the reward of epiphany at the end of it. ${ }^{26}$ That "drama", of course, was to remain a central element throughout, in Baroque architecture and decoration long after the Stanza also. ${ }^{27}$ But its beginnings lay in early Christian decoration schemes.

The final reward of the long road to Salvation, realised at the altar in the host under the guidance of the Trinity, was not only symbolised by but experienced with the help of the materiality of decoration, that created light by the gold of mosaics and by the blue of the celestial firmament with which it alternated in different constellations. In Rome, a specific, local tradition of apse decoration evolved along these lines, the most important characteristics of which are all extremely relevant for the Disputa. ${ }^{28}$ Perhaps 'relevant' is putting it too mildly: to view the Disputa from the perspective of early Christian and medieval iconography, completely changes one's experience not only of the fresco, but of the room.

Contrary to eastern conventions, which always tend to some form of narration in the apse, Roman apses tend to represent an epiphany tout court, without narration. This is not only important because of the evident reflection of this tradition in the Disputa itself. Also, indeed the broad iconographical outline of the Disputa provided the point of departure for the decoration of the entire Stanza, the epiphanic aspects of the School of Athens and the Parnassus are likely to have been spun from this format and should be understood as such. ${ }^{29}$

25 Andaloro M. - Romano S. (eds.), Römisches Mittelalter. Kunst und Kultur in Rom von der Spätantike bis Giotto (Regensburg: 2002) 74.

26 For recent scholarship on Roman apses, see Andaloro - Romano, Römisches Mittelalter and the brilliant study of Erik Thunø (I thank Sible de Blaauw for bringing it to my attention). In the following I paraphrase especially the latter without continuous reference for the sake of brevity.

27 The dramatic aspect has been well studied by Bert Treffers, e.g. Treffers B., Caravaggio e il sacro (Rome: 2015).

28 Thunø, The Apse Mosaic 1-12.

29 The only deviation from these epiphanic aspects is the wall with Justice. This was the wall before which Pope Julius had his throne, providing his personal "perspective", for which see Rijser, Raphael's Poetics $155^{-176}$ with references. 


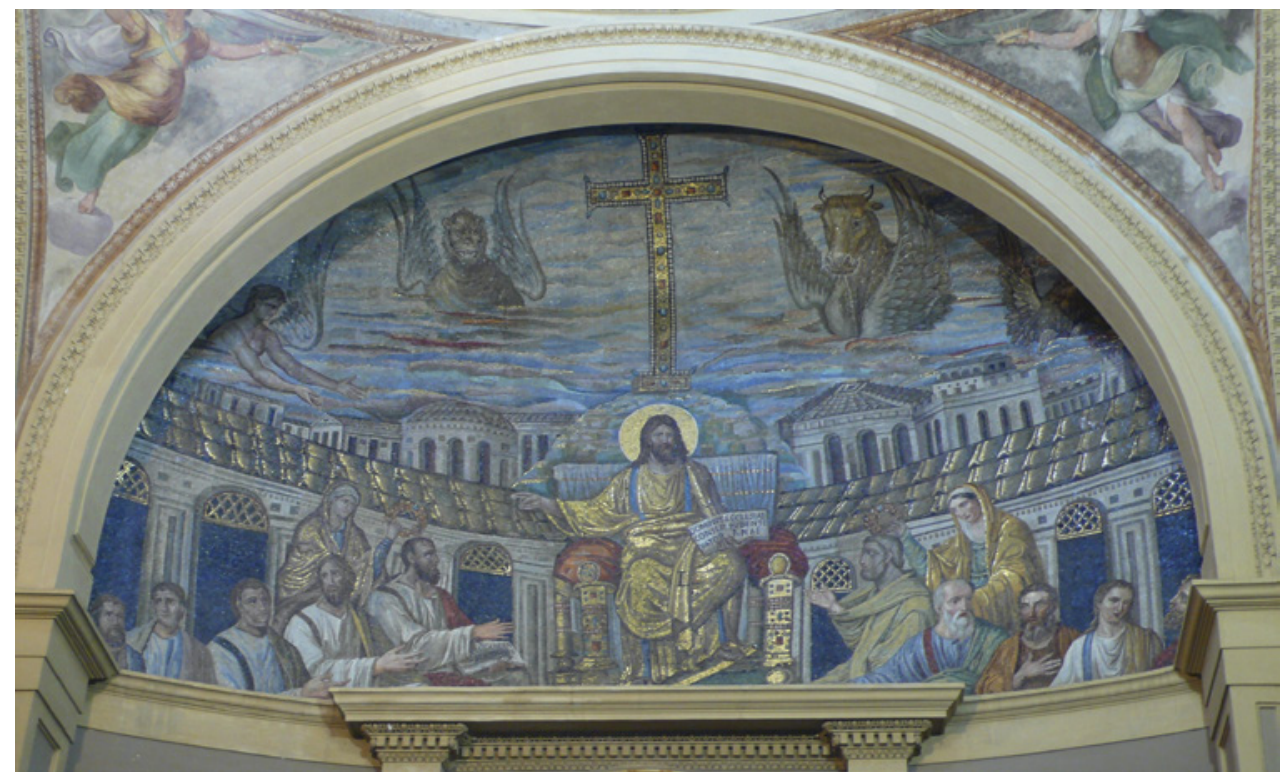

FIgure 4.5 Apse mosaic, Santa Pudenziana, Rome (end of 4th century) IMAGE (C) PUBLIC DOMAIN

In Roman apse-decorations the represented epiphany was centralized by positioning it on the intersection of the horizontal and vertical axes of the visual frame. This graphic format created a virtual cross, but at the same time, in tandem with the cavity of the apse, suggested, and usually displayed, a circle in a variety of forms [Figs. 4.5-4.8].30 The apsidal epiphany is attended by those who are, literally and figuratively, closest to Christ, among whom the Saints that were especially important for the given church, patron and ecclesiastical community, and Rome in general: the Virgin and Saint John, Peter and Paul, Stephen en Laurence, and papal donors. Thus a community of Saints under the guidance of Christ is suggested, a community that extends over the virtual limit of the artistic medium into the space of the church to reach out to those contained within that space, the worshippers, to whom the experience of virtual adoption in this company is the climax of their "pilgrimage" though

3o Or oval, as in the San Clemente apse. Circular motifs abound in the apses, from the prominently displayed halos (e.g. Christ's in the Santa Pudenziana) to wreaths (again the Santa Pudenziana) or acanthus (San Clemente), to the fully divine central circle of the Santa Maria Maggiore, and the hemisphere of God the Father normally superimposed over the epiphany (e.g. Santa Maria in Trastevere). 


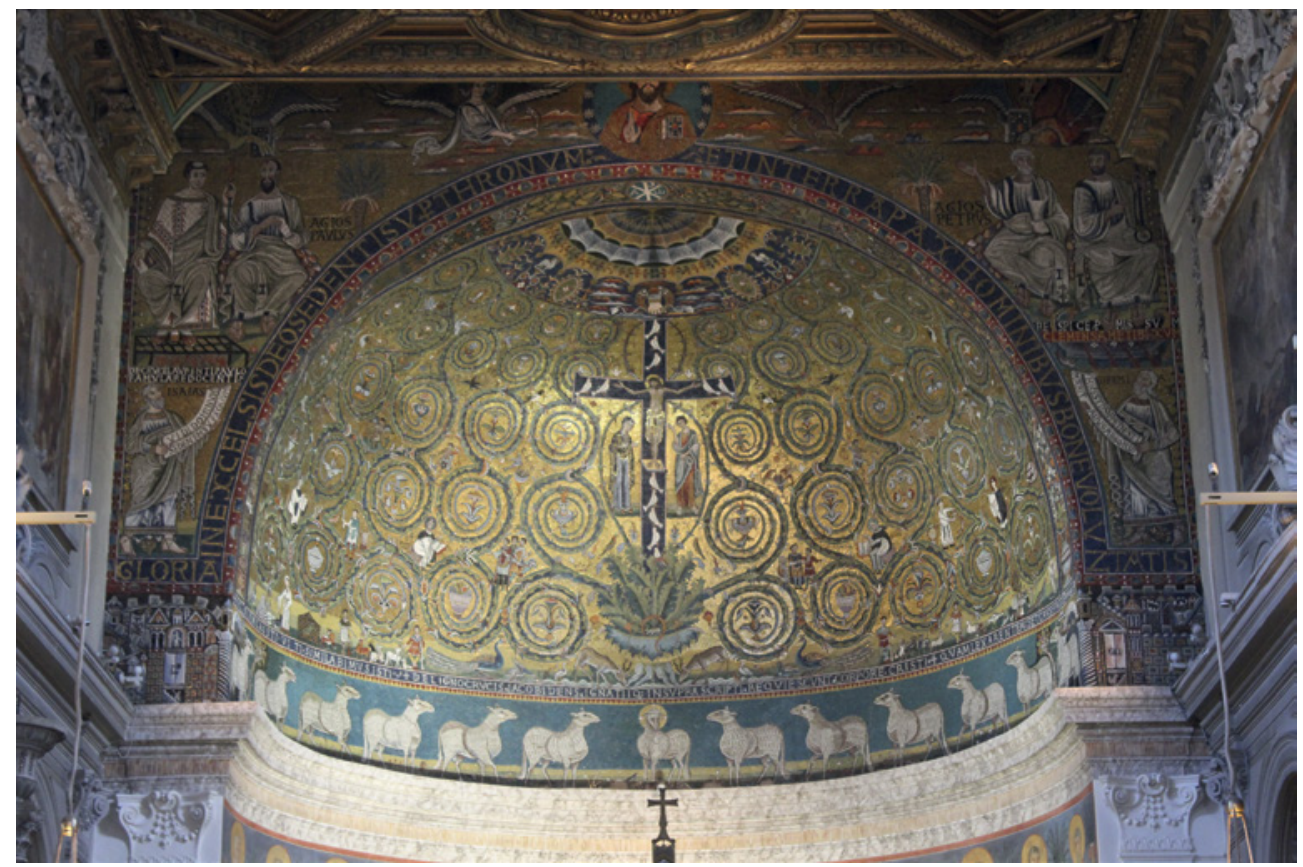

FIGURE 4.6 Apse mosaic, San Clemente, Rome (early 12th century) IMAGE (C) AUTHOR

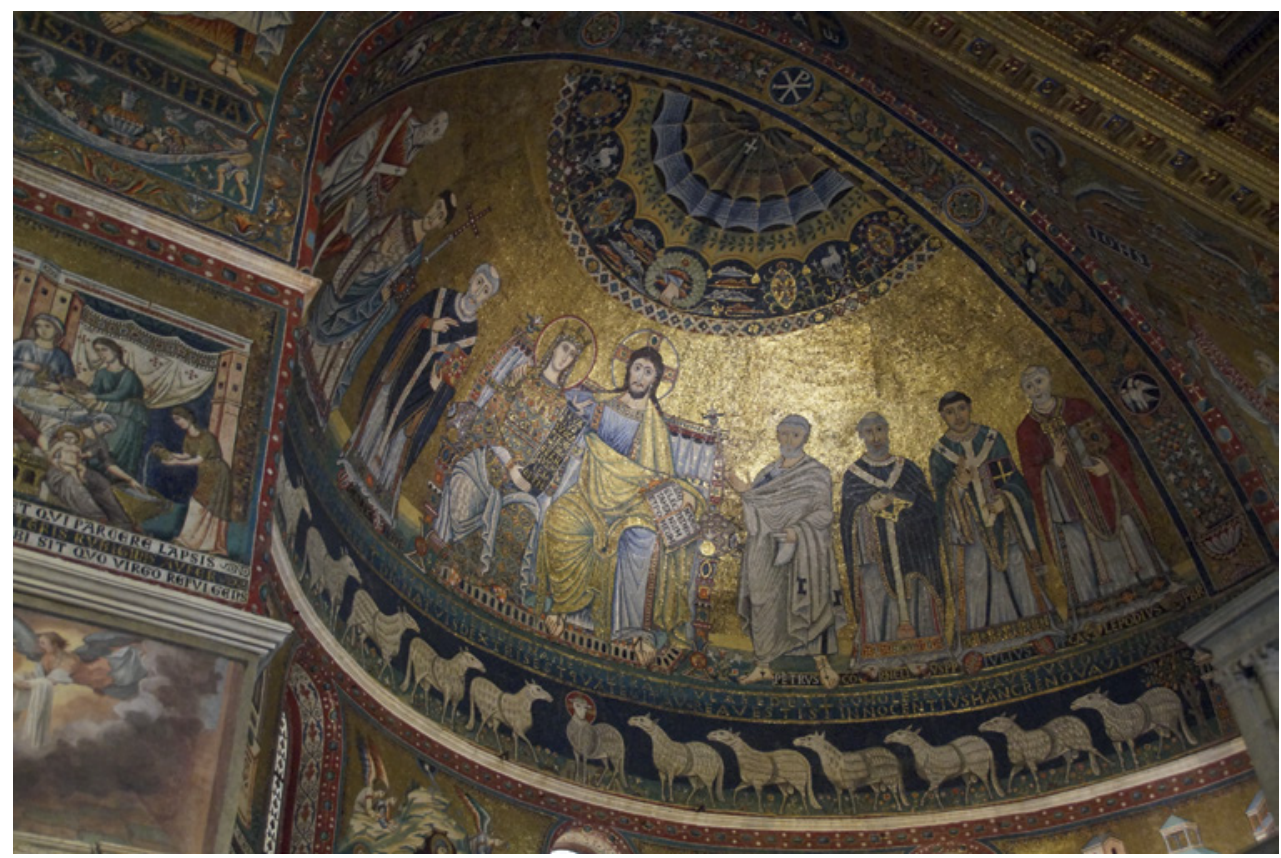

FIGURE 4.7 Apse mosaic, Santa Maria in Trastevere, Rome (mid-13th century) IMAGE (C) MARTJE DE VRIES 


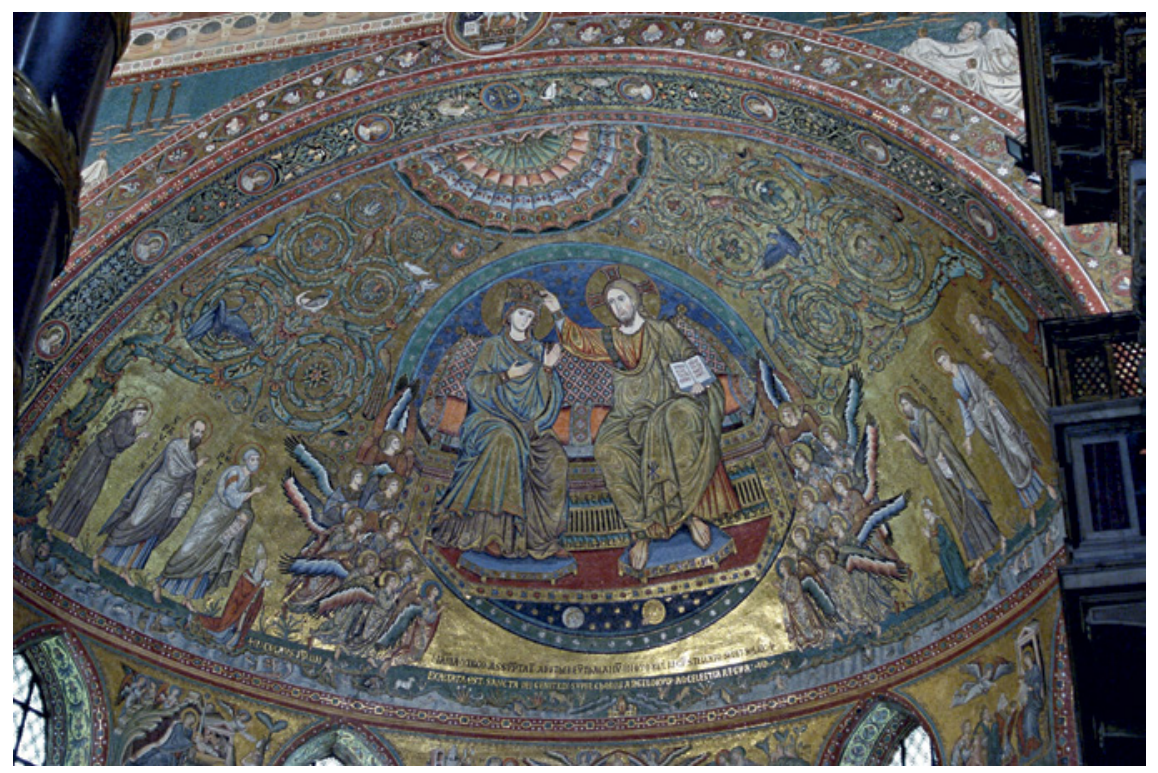

FIGURE 4.8 Apse mosaic, Santa Maria Maggiore, Rome (completed 1296)

IMAGE (CPUBLIC DOMAIN

the Church. This basic design was then set in a colour-scheme dominated by the alternation of blue and gold.

The iconographical themes that are thus allowed to emerge are interconnected. In the first place, Christ is light, and this supernatural light can be experienced in the City of God, of which the earthly city of Rome is a reflection. The typological relation between the two finds its highest realisation in the Incarnation, the absolute reality of which is experienced through the miracle of the Host, the mystery that is in the keeping of the Roman Mother Church, legitimated by the central issue of the apostolic succession. The Incarnation is that of the Word, which also is in the safe keeping of the Church, and is made present in the tradition of Roman apse decoration in prominently displayed inscriptions. This iconographical system, finally, is brought home by a structural interaction with the worshipping viewer whose experience of the reality of the decoration is his Christian reward and strengthens his Christian resolve.

All these elements return in the Disputa, indeed are indispensable for its understanding. Its narration is in fact the epiphany of Christ and His presence in the host. The 'theatre of salvation' is indeed centralised on the intersection of horizontal and vertical lines at the central section of a virtual apse, elegantly combining a thus formed cross motif with four circular motifs of decreasing size, from the hemisphere of the Father to the sun of Christ, to the enveloping circle of the Holy Ghost to the Host, thus revealing the metaphorical light in 
visible splendour, and reality of Incarnation by graphic logic. The composition is brilliantly lit in gold and blue. The correspondence between the City of God and that of men is suggested by the mirroring hemispheres, the lower one aptly flanked by scenes of construction on both sides, in this respect evocative of the building efforts of Pope Julius as well as the metaphorical building that provides access to the Divine. ${ }^{31}$

The careful calibration of Christ on horizontal and vertical axes in the apse tradition has also been connected to the theme of Christ's function as cornerstone, the linchpin around which especially the two apostles Peter and Paul revolve, thus graphically illustrating the concordia apostolorum and Paul's words that 'no longer strangers [...] you are members of the household of God, built upon the foundation of the Apostles and Prophets, with Jesus Christ himself as the cornerstone' (Ephesians 2:20-21). ${ }^{32}$ The theme of cornerstone and/or key - or cap-stone had long ago been identified as a structural theme of the Disputa in a justly famous article by Matthias Winner analysing the personnel of the Disputa as living architecture. ${ }^{33}$ Independently Winner on the Disputa and Thunø on the early medieval Roman apses thus arrived at the same thematic analysis, thus illustrating how unusually strong the continuity between the Disputa and early Roman apses is. Indeed Raphael's summa creates a subtle iconographical amalgam between the different variants available in the Roman tradition, Traditio Legis, Maiestas Domini and Deesis, with special reference, naturally, to the apse of Saint Peter's [Fig. 4.9]. ${ }^{34}$

Of the medieval apses, it has been observed that every apse that connects to the tradition is both an instance of that tradition and a variation and development of it. ${ }^{35}$ With hindsight, and from the perspective of subsequent Classicism it may seem counter-intuitive to approach the Disputa from a perspective such as that. But for any observer in Renaissance Rome, it would of course be the most natural reaction to any evocation of an apse: to take it as an instance, variation and development of the tradition of which it partakes. If we thus take the apse's hint, the Stanza forms the stage for a religious drama, parallel

31 At the same time, the two building sites in the lower register also suggest the iconography of the heavenly Jerusalem and Bethlehem of the apse-tradition.

32 Thunø, The Apse Mosaic 69-72. The correspondence with the School of Athens, by the way, is striking: there also a Concordia between Plato and Aristotle is in the making, but incomplete through the very absence of Christ the Cornerstone.

33 Winner M., "Disputa und Schule von Athen", in Frommel C.L. - Winner M. (eds.), Raffaello a Roma (Rome: 1986) 29-46.

34 The first now lost of course but possibly reflected by copies, see Andaloro - Romano, Römisches Mittelalter 78; for Raphael the restoration by Innocent III, known from Grimaldi's drawing, would have been relevant, for which see ibidem 94-96.

Thunø, The Apse Mosaic 61-62. In this sense iconography parallels certain functions of intertextuality. 


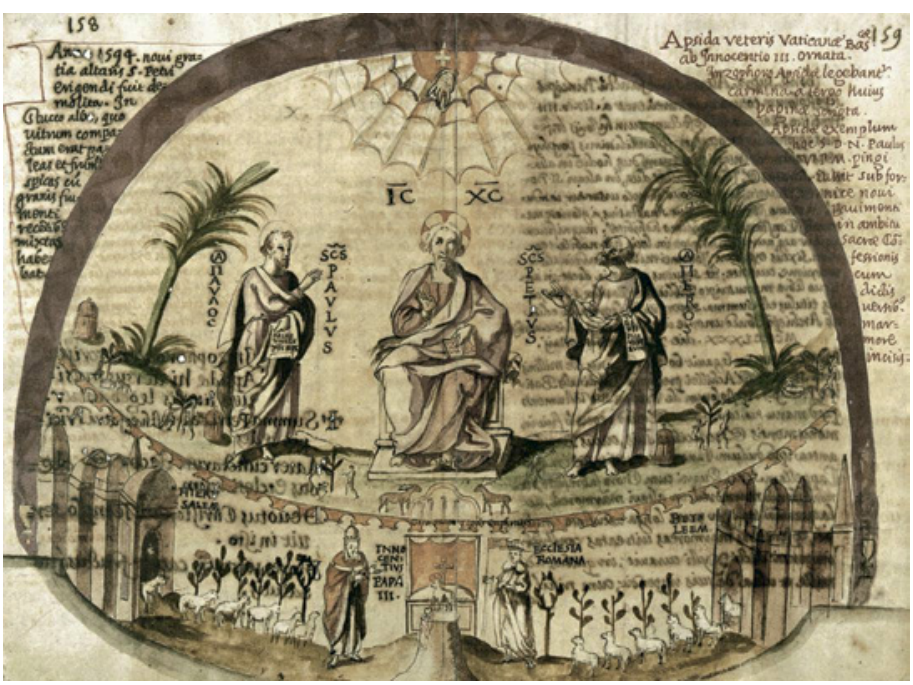

FIG URE 4.9 Giacomo Grimaldi, Old Saint Peter's Apse mosaic. Watercolour, Biblioteca Apostolica Vaticana, Rome IMAGE (C) PUBLIC DOMAIN

to the sacred space of a Roman Church it evokes. This drama is hosted by the patron, Pope Julius, who officiated from his throne before the Justice wall and thus from a position exactly parallel to that of the officiating pontiff in the Sistine Chapel. ${ }^{36}$ The drama enacted by the line-up of Saints on the apses of Roman churches essentially is a virtual realisation of a communio Sanctorum of which the worshiper is allowed to partake through interaction with the decoration. ${ }^{37}$ That function the Disputa in particular performs in a spectacular and triumphant way: it creates a trans-historical community of Saints that interact through diverse figures (leaning over the parapet, pointing at the room etc.) and graphical expedients, with those present in the room..$^{38}$ Of course, it must be added that the corpus of saints is significantly enriched in the room, with poets, philosophers and contemporaries. Thus Julius' dreams of the universal, triumphant church in Rome were virtually realized as one trans-historical, 'living' assembly through the brilliant use of the medium of art.

$36 \quad$ Rijser, Raphael's Poetics 156, with references.

37 Thunø, The Apse Mosaic 172-206.

38 This interaction has usually been interpreted as an illusionistic device and thus as a specifically artistic triumph; for other possible resonances see Rijser, Raphael's Poetics 123-130. 
The emphatic presence of inscriptions in the apsidal tradition also returns in the Disputa, through the incipit of each Gospel at the very centre of the Disputa. Acquiring special emphasis by way of its position as the last, that of John reads: 'In principio erat Verbum et Verbum erat apud Deum et Deus erat Verbum'. The identification of God with the Word in this text, immensely important as it is for scriptural traditions in the Middle Ages and beyond, also helps explain the extraordinarily high status of scripture in the Stanza. That books and text are so important in this room gave rise to the hypothesis that the Segnatura was Julius' library. But from the perspective of the apse-tradition, in combination with the incipit of John, such a hypothesis is hardly necessary, indeed seems over-literally minded. The Word Made Flesh, such was the discourse of the apse-tradition, gives light to the world as Logos shines in the darkness. In other words, we do not need to think of the Stanza as a library to understand the thematic emphasis on the Word, but should rather think of the medieval iconographical tradition. ${ }^{39}$

Thus Raphael's Disputa summarizes and brings to fruition the great tradition of the Roman Church in its architectural and iconographical presence in Rome. If so, the basic question that emerges is, why? This hall is not a Church. Rather than a library, a function like that of an oval office seems most plausible. ${ }^{40}$ But then, it is the office of the prince of the Church of Rome. As such the room functions as a performative illustration of the protection the Pontiff gives to the Church: as the purveyor and guarantor of the Justice he presides on his throne in front of the wall devoted to that virtue, in a room that replicates in ever decreasing scale the format of, first Saint Peter's (to-be at the time), then the Sistine Chapel. As a secular space the room displays pontiffs crowned with the tiara they were only allowed to wear outside of church, but it represents their legitimacy through apostolic succession. It does so because here, in this very room, the pontiff functions as prince, ratifying appointments, dispensing justice. He does so as princely protector of the Church and its tradition that are represented virtually in the room. ${ }^{41}$

39 Shearman's library-hypothesis ultimately rested on the observation that 'it is all so terribly bookish', in Shearman J., "The Vatican Stanze: Functions and Decoration", in Holmes G. (ed.), Art \& Politics in Renaissance Italy (Oxford: 1993). For persuasive opposition to that hypothesis see Kempers B., "Words, Images and All the Pope's Men: Raphael's Stanza della Segnatura and the Sythesis of Divine Wisdom", in Hampsher-Monk I. (ed.), History of Concepts: Comparative Perspectives (Amsterdam: 1998) 131-165.

40 Kempers, "All the Pope's Men".

41 O'Malley J.W., "The Religious and Theological Culture of Michelangelo's Rome, 1508-1512", in Sears E. (ed.), The Religious Symbolism of Michelangelo. The Sistine Ceiling (Oxford: 2000) xli-lii. 
Earlier points of view taken on the reconstruction of the chronology of Raphael's frescoes in the Stanza della Segnatura, an issue of long-standing dispute, appear to have a fascinating relationship with the views the given critic entertains on the Middle Ages. Vasari had stated in his Vita that the School of Athens was painted prior to the Disputa. But this position was subsequently over-ruled by Bellori a century later, who proposed that the Disputa had precedence, a hypothesis that has been usually followed. Technical data provided by recent restorations now finally seem to clinch the matter: they have confirmed that although Raphael set out to paint the wall of the Disputa first after the ceiling, work in this area most probably was interrupted and Raphael apparently, after a first stage of planning, temporarily dropped the Disputa and went over to the facing wall with the School of Athens. ${ }^{42}$ Now an unusual amount of preparatory drawings for the Disputa survive, showing that the overall scheme was drastically altered in the process of composition and this confirms that the road to the final composition was tortuous and difficult - none of these drawings, by the way, deviates from the format of a symmetrical centralized epiphany continuous with the apse tradition, concordia apostolorum included. ${ }^{43}$ But what these drawings do show is that, more than on any other fresco in the room, Raphael was experimenting and no doubt consulting and discussing with patron and advisors on the iconography. Why would this be so? For the very reason, of course, that the great medieval tradition was at stake in the fresco, and had to be argued through and through, discussed again and again: as Arnold Nesselrath has observed, in this fresco in particular Raphael was under constant surveillance of curial theologians, on a subject that was absolutely central to the papacy. ${ }^{44}$

As said, it was Bellori who proposed that Raphael painted the Disputa first in his description of the Segnatura, thus contradicting Vasari. Bellori's agenda was to articulate Classicism as the core of l'idea del bello, and Raphael as the epitome of this classicist idealism. Now, for the sake of this argument, he employed an interesting form of historicism. The 'traditional' nature of the Disputa on which we have commented above, is configured by him not as a conscious reflection of tradition, but as a trace of the Medievalism that Raphael subsequently was to supersede in the most spectacular way. Therefore Bellori states that 'Raphael still upheld in this, his first composition, some traits of the old painters [such as in the naive depiction of the Holy Father with Seraphim],

42 Nesselrath, "Raphael and Pope Julius" 285-288.

43 A representative sample in Chapman - Henry - Plazotta, Raphael 232-243 (cat. 78-86).

44 Ibidem 288. 
following the old habit of using gold-ground. ${ }^{45}$ Recent restoration, by the way, has shown that this simply is not true: Raphael did not use gold-ground, but brilliantly employed yellow pigments to suggest gold. ${ }^{46}$ But most importantly in the present context, Bellori does recognize Raphael's medievalism, yet ascribes it to immaturity: the culmination of his spectacular development, according to him, was yet to come, in the School of Athens, and therefore Bellori singles out that fresco as the artistic end in which all previous development culminated. Such a reading exactly reverses the conceptual, theological and intellectual priorities we suggested above in this chapter, not to speak of the spatial movement, for Plato and Aristotle are after all walking towards the altar on the other side. Furthermore, by stating that we should call the fresco on the west wall the 'gymnasium of Athens', adding this is common practice, although actually the first time this predecessor of what would be simplified as school is used as title, Bellori defines the subject of the fresco as classical, setting up an opposition with the "retrograde" Middle Ages. ${ }^{47}$ But as we have seen, neither is the School of Athens classical - it is trans-historical - nor is the Disputa Medieval: the opposition simply does not apply. Bellori's configuration of the Medieval as old-fashioned and classicism as new may have certain grounds; but it also seriously misrepresents what Raphael was trying to achieve in the Disputa: a conscious emulation of the great medieval Roman decorative tradition.

\section{Selective Bibliography}

Andaloro M. - Romano S. (eds.), Römisches Mittelalter. Kunst und Kultur in Rom von der Spätantike bis Giotto (Regensburg: 2002).

Bellori Giovanni Pietro, Descrizione delle imagini dipinte da Rafaelle d'Urbino nelle camere del Palazzo Apostolico Vaticano (Rome, eredi Barbiellini: 1751).

45 'Rafaelle in questo suo primo componimento ritenne qualche tratto de' vecchi Pittori, e sopra nella gloria degl'Angioli intorno al Padre Eterno divise in fasce li Serafini l'uno sopra l'altro direttamente, confor - me la simplicità di quei primi. Seguitò egli ancora il vecchio costume di toccar d'oro gli splendori de' Santi, gl'habiti, gli ornamenti per dar lustro a i colori, et arrichirne l'istoria, come si vede nella sfera di luce che circonda Cristo, nella quale, oltre il campo d'oro puro, accioché meglio spicasse il fulgore, sono puntati li raggi con bollette dorate, ed arricchiti gl'abiti di ricami d'oro'. Bellori Giovanni Pietro, Descrizione delle imagini dipinte da Rafaelle d'Urbino nelle camere del Palazzo Apostolico Vaticano (Rome, eredi Barbiellini: 1751) 27.

46 Nesselrath, "Raphael and Pope Julius" 288.

47 Kempers, "All the Pope's Men" 140-144. 
Kempers B., "Words, Images and All the Pope's Men: Raphael's Stanza della Segnatura and the Sythesis of Divine Wisdom", in Hampsher-Monk I. (ed.), History of Concepts: Comparative Perspectives (Amsterdam: 1998) 131-165.

Nagel A. - Wood C.S., Anachronic Renaissance (New York: 2010).

Nesselrath A., "Raphael and Pope Julius II", in Chapman H. - HenryT. - Plazotta C. (eds.), Raphael, from Urbino to Rome, exh. cat., The National Gallery London (London: 2004).

Nesselrath A., "Raffaels Madonna von Foligno", in Henning A. - Nesselrath A. (eds.), Himmlischer Glanz. Raffael, Dürer und Grünewald malen die Madonna, exh. cat., Old Masters Gallery Dresden (Munich: 2012).

Rijser D., Raphael's Poetics. Art and Poetry in High Renaissance Rome (Amsterdam: 2012).

Shearman J., "The Vatican Stanze: Functions and Decoration", in Holmes G. (ed.), Art \& Politics in Renaissance Italy (Oxford: 1993).

Shearman J., Raphael in Early Modern Sources (New Haven: 2003).

Thunø E., The Apse Mosaic in Early Medieval Rome. Time, Network and Repetition (Cambridge: 2015).

Winner M., "Disputa und Schule von Athen", in Frommel C.L. - Winner M. (eds.), Raffaello a Roma (Rome: 1986) 29-46. 